\title{
混合主成分分析による部材断面表現を用いた鋼構造骨組の最適設計法 OPTIMUM DESIGN METHOD OF STEEL BUILDING FRAMES USING EXPRESSION OF A MEMBER SECTION BASED ON MIXTURES OF PROBABILISTIC PRINCIPAL COMPONENT ANALYZERS
}

\author{
山川 誠*, 吉富信太*, 上谷宏二** \\ Makoto YAMAKAWA, Shinta YOSHITOMI and Koji UETANI
}

\begin{abstract}
A method is proposed for expressing reduced member dimensions of an optimization problem. This method is based on mixture model for probabilistic principal component analyzers for feature extraction of given member section list, whose parameter can be determined using an expectation-maximization algorithm. In this paper, a new efficient method enables to find an optimum set of member sections of the steel building frames so that total weight would be minimum subject to constraints on interstory drifts under design spectrum-compatible earthquakes.
\end{abstract}

\section{Keywords : steel building frames, minimum weight design, response analysis, rolled steel, mixtures of probabilistic principal component analyzers 鋼構造骨組，最小重量設計，応答解析，ロール材，混合主成分分析}

\section{1. はじめに}

鋼構造建築骨組を対象として，構造設計を論理的に行うための研 究が数多くなされているにも関わらず，実務の構造設計にはあまり とりいれられていない現状にある。そ理由の一つとして，設計者 が望むような形での論理化がなされていないことが考えられる. 最 小重量設計ではわずかしか違わない目的関数の下で許容解が多数存 在することがしばしばあるが，設計においては必ずしも正確な大域 的最適解が必要とされるわけではない，そこでは，建設可能である ような性質のよい局所最適解を効率的に求められる手法が望まれる.

構造設計の実務に用いられる鋼材として，ロール材とよばれる規 格品と，任意の寸法で製作する溶接組み立て材 BH（Built UP H） や BB（Built UP Box）がある. BH や BB は加工手間が大きいた め，現状の実務設計ではできるだけロール材から部材選択を行いた いという要請がある.

与えられた有限個の種類の $\mathrm{H}$ 形鋼材断面で構成された部材断面 集合を部材断面リストとする. 既往の研究では，ロール材を想定し て部材断面性能を部材断面積の関数として表現すること例えは 1),2) が 多い、しかし，このような方法では，ロール材あるいは設計者が指 定する部材断面リストに含まれる部材断面の特徴を充分に表現する ことは難しく, 部材断面形状を推測することもできない.そのため， 各層の梁せいをそろえたいといった接合部設計面からの要求などの 部材断面形状に関する制約条件を考慮することは困難である．部材 せいを離散最適化問題として取り扱う方法は提案されているが 3),
連続変数最適化問題として精度よく取り扱うことができる方法は著 者が知る限り提案されていない. 連続変数最適化問題における解が 得られれば，近傍に探索範囲を絞りこむことや初期解として用いる ことにより，効率的に離散最適解を導くことも可能である.

連続変数最適化問題として定式化するために, $\mathrm{H}$ 形鋼の部材断面 を, せい, 幅; ウェブ板厚, フランジ板厚の物理的に独立な形状に 関する四成分により表現し，これらをそのまま設計変数とした問題 を考えることもできる.しかし，ロール材の形状に関する各成分は, 実際にはある相関関係を持って分布しており，形状に関する各成分 を独立な設計変数として扱うだけでは，ロール材としては非現実的 な形状が解として得られることが予想される. また，一つの断面に 四つの設計変数が必要となってしまう.

骨組構造を対象とする最適化問題では，計算量が多くなることが 予想されるため，できるだけ少ない成分で問題を記述できることに は意義がある，本論文では，同じ部材せいである等の共通した特徵 を有する部材断面の集合を系列として，どの系列に属するかの部材 断面系列指標と各系列内での主成分を部材断面系列内指標として, 部材断面の各成分の分布を確率モデルとして表現する手法を提案す る. 本論文で用いる表記を Appendix1にまとめる.

提案する部材断面表現を用いれば，次のような利点がある。（1） 特徵を抽出した空間で変数表現を行うので, 物理的な空間での変数 表現よりも小さな次元で問題を記述でき, 問題全体の自由度を减じ ることができる．（2）与えられた部材断面リストにおける部材断面

\footnotetext{
* 京都大学大学院工学研究科建築学専攻 大学院生. 工修

** 京都大学大学院工学研究科建築学専攻 教授 $\cdot$ 工博
}

Graduate Student, Dept. of Architecture and Architectural Eng., Graduate School of Eng., Kyoto University, M. Eng.

Prof., Dept. of Architecture and Architectural Eng., Graduate School of Eng., Kyoto University, Dr. Eng. 
の各成分分布が考虑されているので，与えられた部材断面リストに 近い部材断面が解として得られる.

\section{2. 確率モデルに基づく部材断面表現}

\section{1. 確率的主成分分析モデル}

確率的主成分分析(Probabilistic Principal Component Analysis) は，隠れ変数を含んだ確率モデルを用いて主成分分析を再定式化し たモデルである ${ }^{4)}$. 本論文においては, 部材断面における主成分を $x$ として抽出する.

同じ部材せいである等の共通の特徵を有する部材断面の集合を 部材断面系列と定義し，同一の部材断面系列に属する各部材断面の 性能は指数的に比例関係にあると仮定し,対数空間で変数を考える 部材断面に関する量を $d$ 次元の観測変数 $\boldsymbol{y}_{p}$ として, 例えば次式のよ うに定義する.

$$
\boldsymbol{y}_{P}=\left\{\begin{array}{lllllll}
\ln A & \ln I_{x} & \ln I_{y} & \ln Z_{x} & \ln Z_{y} & \ln Z_{p x} & \ln Z_{p y}
\end{array}\right\}^{T}
$$

ここで, $A, I_{x}, I_{y}, Z_{x}, Z_{y}, Z_{p x}, Z_{p y}$ は，それぞれ断面積， 強軸周りおよび弱軸周りの断面二次モーメント，強軸周りおよび弱 軸周りの断面係数, 強軸周りおよび弱軸周りの塑性断面係数とする.

同一の部材断面系列においては隠れ変数である $x$ の線形変換とノ イズ $\varepsilon_{P}$ から観測変数 $y_{p}$ が生成されるとして, 次式のように表す。

$$
y_{p}=W x+\mu_{P}+\varepsilon_{P}
$$

ここで, $\boldsymbol{W}, \boldsymbol{\mu}_{P}, \varepsilon_{P}$ は $d$ 次元ベクトルであり，それぞれ主軸， 平均，ノイズを表す．主成分分析を考える場合には，ノイズ $\varepsilon_{P}$ は各 成分で独立に等しく生じるとして，次の正規分布に従うとする.

$$
p\left(\varepsilon_{P}\right)=\mathcal{N}\left(\varepsilon_{P} ; \boldsymbol{o}, \sigma_{P}{ }^{2} I_{d}\right)
$$

ここで, $\sigma_{P}{ }^{2}$ はノイズの分散, $I_{d}$ は $d$ 次元単位行列とし， $p(\cdot)$ は 確率密度関数, $\mathcal{N}(; \mu, \Sigma)$ は平均 $\mu$, 共分散行列 $\Sigma$ からなる多次元 正規分布とする. 図 1 に主成分分析モデルにおける $W ， \mu_{P}$ の概念 図を示す（2)，(3)式より $x$ が与えられた下での $y_{P}$ の条件つき確率 密度関数は

$$
p\left(\boldsymbol{y}_{P} \mid x\right)=\mathcal{N}\left(\boldsymbol{y}_{P} ; \boldsymbol{W} x+\boldsymbol{\mu}_{P}, \sigma_{P}{ }^{2} \boldsymbol{I}_{d}\right)
$$

と表せる. $x$ は抽出される隠れ変数であるが, 平均 0 , 分散 1 の正 規分布に従うとする。

$$
p(x)=\mathcal{N}(x ; 0,1)
$$

隐れ変数 $x$ と観測変数 $\boldsymbol{y}_{P}$ の同時確率密度関数は(4), (5)式より

$$
\begin{aligned}
p\left(x, \boldsymbol{y}_{P}\right) & =p\left(\boldsymbol{y}_{P} \mid x\right) p(x) \\
& =\mathcal{N}\left(\boldsymbol{y}_{P} ; \boldsymbol{W} x+\boldsymbol{\mu}_{P}, \sigma_{P}{ }^{2} \boldsymbol{I}_{\boldsymbol{d}}\right) \mathcal{N}(x ; 0,1)
\end{aligned}
$$

と表せる。

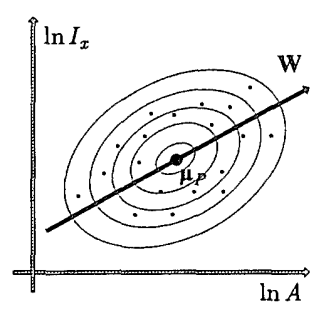

主成分分析

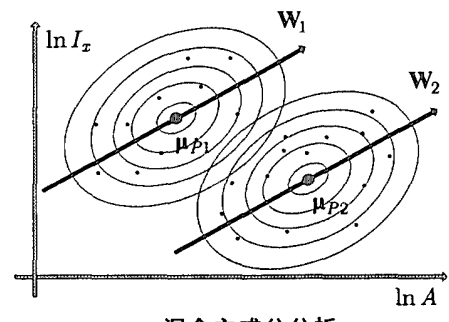

混合主成分分析
図 1 主成分分析と混合主成分分析

\section{2. 系列を考慮した混合主成分分析モデル}

部材断面リストがある一つの部材断面系列に属するとみなせる のであれば，前節までの主成分分析モデルにより部材断面を精度よ く表現可能である。しかし，実際には特徽が明らかに異なり，複数 の(2)式が必要となる場合が多い, よって, 本論文では混合主成分分 析を用いて部材断面表現を行う。混合主成分分析（Mixtures of Probabilistic Principal Component Analysis）はデータ空間のクラ スタリングと主成分分析モデルを併用することによって特徵空間の 構成を行う 4),5).データに複数の主軸が存在するような場合には, 図 1 に示すように混合主成分分析が適している，混合正規分布モデ ルにおける様々な表現 6ににおいて, 混合主成分分析モデルが多くの 場合で有利なモデルの一つであることが示されている7.

混合主成分分析による特徴抽出とあわせて, 系列を考慮するため の部材断面系列指標を導入して，部材断面を確率的に表現する. 部 材断面に関する量 $y$ を, 部材断面系列の指標とする成分 $y_{S}$ と残りの $d$ 次元の成分 $y_{P}$ とにうけて表す.

$$
y=\left\{\begin{array}{ll}
y_{S} & y_{P}^{T}
\end{array}\right\}^{T}
$$

$y_{P}$ に対応する主成分を $x$ として, 特徵空間における独立な成分 を $y_{S}, x$ の二成分とする. 部材せい $H$ が部材断面系列指標 $y_{S}$, 残 りの成分が $y_{P}$ となるような部材断面を考え次式のように定義する.

$$
y_{S}=\ln H
$$

$$
\boldsymbol{y}_{P}=\left\{\begin{array}{lllllll}
\ln A & \ln I_{x} & \ln I_{y} & \ln Z_{x} & \ln Z_{y} & \ln Z_{p x} & \ln Z_{p y}
\end{array}\right\}^{T}
$$

ある与えられた部材断面系列 $m_{i} ; i=1, \cdots, M$ に対して, 前節同様 に隠れ変数 $x$ の線形変換とノイズから観測変数 $y_{S}, \boldsymbol{y}_{P}$ が生成され るものとする. $y_{S}$ は部材断面系列指標であるので, 同一の部材断面 系列において $x$ に関わらずほぼ等しい值となるとして，部材断面系 列 $m_{i}$ が与えられた下での $y_{S}, y_{P}$ をそれぞれ次式のように仮定する。

$$
\begin{gathered}
y_{S}=\mu_{S i}+\varepsilon_{S i} \\
\boldsymbol{y}_{P}=\boldsymbol{W}_{i} x+\boldsymbol{\mu}_{P i}+\boldsymbol{\varepsilon}_{P i}
\end{gathered}
$$

前節同様に $W_{i}, \mu_{P i}, \varepsilon_{P_{i}}$ は $d$ 次元ベクトルとする.ノイズ $\varepsilon_{S i}, \varepsilon_{P i}$ は次の正規分布に徉うとする。

$$
\begin{gathered}
p\left(\varepsilon_{S i}\right)=\mathcal{N}\left(\varepsilon_{S i} ; 0, \sigma_{S i}{ }^{2}\right) \\
p\left(\boldsymbol{\varepsilon}_{P i}\right)=\mathcal{N}\left(\boldsymbol{\varepsilon}_{P i} ; \boldsymbol{O}, \sigma_{P i}{ }^{2} \boldsymbol{I}_{d}\right)
\end{gathered}
$$

隠れ変数 $x$ は平均 0 , 分散 1 の正規分布に従うとすれば, 部材断面 系列 $m_{i}$ が与えられた下での䧌れ変数 $x$ と観測変数 $y$ の同時確率密 度関数は, 系列に関する正規分布モデルと確率的主成分分析モデル を用いて，次式のように表せる.

$$
\begin{aligned}
p\left(x, y \mid m_{\boldsymbol{i}}\right)= & p\left(y_{S} \mid m_{\boldsymbol{i}}\right) p\left(\boldsymbol{y}_{P} \mid x, m_{\boldsymbol{i}}\right) p(x) \\
= & \mathcal{N}\left(y_{S} ; \mu_{S i}, \sigma_{S i}{ }^{2}\right) \\
& \times \mathcal{N}\left(\boldsymbol{y}_{P} ; \boldsymbol{W}_{i} x+\boldsymbol{\mu}_{P i}, \sigma_{P_{i}}{ }^{2} \boldsymbol{I}_{\boldsymbol{d}}\right) \mathcal{N}(x ; 0,1)
\end{aligned}
$$

(14)式の混合モデルは次式のように与えられる.

$$
\begin{aligned}
p(x, \boldsymbol{y})= & \sum_{i=1}^{M} \pi_{i} p\left(x, \boldsymbol{y} \mid m_{i}\right) \\
= & \sum_{i=1}^{M} \pi_{\boldsymbol{i}}\left\{\mathcal{N}\left(y_{S} ; \mu_{S i}, \sigma_{S i}{ }^{2}\right)\right. \\
& \left.\quad \times \mathcal{N}\left(\boldsymbol{y}_{P} ; \boldsymbol{W}_{i} x+\boldsymbol{\mu}_{P i},{\sigma_{P i}}^{2} \boldsymbol{I}_{d}\right) \mathcal{N}(x ; 0,1)\right\}
\end{aligned}
$$


ここで, $\pi_{i}$ は混合比であり, 次式を満たす。

$$
\sum_{i=1}^{M} \pi_{i}=1
$$

$m_{i}$ に対応するモデルパラメータを $\theta_{i}$ とし，次式のように定義する.

$$
\theta_{i}=\left\{\begin{array}{llllll}
\pi_{i}, & \mu_{S i}, & \sigma_{S i}{ }^{2}, & W_{i}, & \mu_{P i}, & \sigma_{P i}{ }^{2}
\end{array}\right\}
$$

パラメータ全てをまとめて $\theta=\left\{\theta_{i} ; i=1, \ldots, M\right\}$ と表す. 与えられた $N$ 種類の部材断面からなる集合を部材断面リストと呼び, 部材断面 リストの $n$ 番目に登録された対数空間上の部材断面に関する量を 観測変数 $\boldsymbol{y}_{n}$ とし, 観測変数のサンプルと呼ぶ. また $\boldsymbol{y}_{n}$ において, $y_{S}$, $y_{P}$ に対応する成分をそれぞれ $y_{S n}, y_{P n}$ と表す（15)式より対数尤 度関数は

$$
\mathcal{L}(\theta)=\sum_{n=1}^{N} \ln \left\{\sum_{i=1}^{M} \pi_{i} p\left(x_{n}, \boldsymbol{y}_{n} \mid m_{i} ; \theta\right)\right\}
$$

と表される (Appendix 2). (18)式を最大化するモデルパラメータ $\theta$ が最尤推定量となり，部材断面リストに対して最も適合する確率分 布である.ただし， $\sigma_{S i}{ }^{2}$ に関しては系列の分散を表す值であり，系 列の領域を決めるパラメータとも解釈されるので, 指定值 $\bar{\sigma}_{S i}{ }^{2}$ を与 えるものとする

Newton 法や勾配法により(18)式から最尤推定量を直接求めるこ とも可能であるが, 計算が煩雑になり多くの計算量が必要とされる ため，本論文では EM 法による最尤推定を行う．EM 法は観測でき ない隐れた変数が存在する時に最尤推定を行うための沉用手法であ る. 各データがどのモデルから生起したかを示す確率変数 $z=\left\{z_{i} ; i=1, \cdots, M\right\}$ を導入する. 各成分 $z_{i}$ は 0 か 1 の值をとり, $z_{i}=1$ は部材断面系列 $m_{i}$ から観測変数が生起したことを意味す る.この隠れ変数 $z$ を用いれば, 対数尤度関数は

$$
\mathcal{L}_{\mathcal{C}}(\theta)=\sum_{n=1}^{N} \sum_{i=1}^{M} z_{n i} \ln \left\{\pi_{i} p\left(x_{n}, y_{n} \mid m_{i} ; \theta\right)\right\}
$$

と表せる．(19)式を最大化する $\theta$ は最尤推定量である．EM 法では $\mathrm{E}$ ステップと $\mathrm{M}$ ステップを逐次反復することにより, モデルパラメ 一タ $\theta$ の最尤推定量 $\hat{\theta}$ が漸近的に求められる.

\section{・ E(Expectation)ステップ}

観測変数のサンプルが与えられた下での対数尤度関数の条件つ

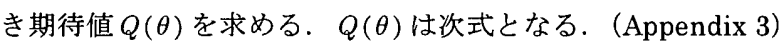

$$
\begin{aligned}
Q(\theta)=\sum_{n=1}^{N} & \sum_{i=1}^{M} R_{n i}\left\{\ln \pi_{i}-\frac{1}{2} \ln {\sigma_{P i}}^{2}-\frac{1}{2}\left\langle x_{n i}{ }^{2}\right\rangle\right. \\
& -\frac{1}{2 \sigma_{P i}{ }^{2}}\left\|y_{P n}-\boldsymbol{\mu}_{P i}\right\|^{2}+\frac{1}{\sigma_{P i}{ }^{2}}\left\langle x_{n i}\right\rangle \boldsymbol{W}_{i}{ }^{T}\left(\boldsymbol{y}_{P n}-\boldsymbol{\mu}_{P i}\right) \\
& \left.-\frac{1}{2 \sigma_{P i}{ }^{2}} W_{i}{ }^{T} W_{i}\left\langle x_{n i}{ }^{2}\right\rangle-\frac{1}{2 \sigma_{S i}{ }^{2}}\left\|y_{S n}-\mu_{S i}\right\|^{2}\right\}
\end{aligned}
$$

ここで

$$
\begin{gathered}
C_{x i}=\sigma_{P i}{ }^{2}+\boldsymbol{W}_{i}{ }^{T} \boldsymbol{W}_{i} \\
\boldsymbol{C}_{y i}=\sigma_{P i}{ }^{2} \boldsymbol{I}_{d}+\boldsymbol{W}_{i} \boldsymbol{W}_{i}^{T} \\
\left\langle x_{n i}\right\rangle=E\left(x \mid \boldsymbol{y}_{n}, m_{i}\right)=C_{x i}{ }^{-1} \boldsymbol{W}_{i}{ }^{T}\left(\boldsymbol{y}_{P n}-\boldsymbol{\mu}_{P i}\right) \\
\left\langle x_{n i}{ }^{2}\right\rangle=E\left(x^{2} \mid \boldsymbol{y}_{n}, m_{i}\right)=\sigma_{P i}{ }^{2} C_{x i}{ }^{-1}+\left\langle x_{n i}\right)^{2} \\
R_{n i}=\frac{\pi_{i} \mathcal{N}\left(y_{S} ; \mu_{S i}, \sigma_{S i}{ }^{2}\right) \mathcal{N}\left(\boldsymbol{y}_{P} ; \boldsymbol{\mu}_{P i}, C_{y i}\right)}{\sum_{j=1}^{m} \pi_{j} \mathcal{N}\left(y_{S} ; \mu_{S i}, \sigma_{S j}{ }^{2}\right) \mathcal{N}\left(\boldsymbol{y}_{P} ; \mu_{P j}, C_{y j}\right)}
\end{gathered}
$$

である.

\section{・M(Maximization)ステップ}

対数尤度関数の期待值である $Q(\theta)$ を最大化するようにパラメー 夕 $\theta$ を更新する。このようなパラメータ $\theta$ は，(16)式を制約条件と するラグランジュ乗数法により求められる. パラメータ間には相互 関係が存在するが，本研究では一般化 EM 法により，次式のように 更新を行う。

$$
\begin{gathered}
\tilde{\pi}_{i}=-\frac{1}{N} \sum_{n=1}^{N} R_{n i} \\
\boldsymbol{\mu}_{P i}=\frac{\sum_{n=1}^{N} R_{n i}\left\{\dot{y}_{P n}-\left\langle x_{n i}\right\rangle \boldsymbol{W}_{i}{ }^{T}\right\}}{\sum_{n=1}^{N} R_{n i}} \\
\tilde{W}_{i}=\frac{\sum_{n=1}^{N} R_{n i}\left\langle x_{n i}\right\rangle\left(y_{P n}-\tilde{\mu}_{P i}\right)}{\sum_{n=1}^{N} R_{n i}} \\
\sum_{n=1}^{N} R_{n i}\left\langle x_{n i}{ }^{2}\right\rangle \\
\sum_{P i}{ }^{2}=\frac{(26)}{\sum_{n=1}^{N} R_{n i}\left\{\left\|\boldsymbol{y}_{P n}-\tilde{\boldsymbol{\mu}}_{P i}\right\|^{2}-2\left\langle x_{n i}\right\rangle \tilde{W}_{i}^{T}\left(\boldsymbol{y}_{P n}-\tilde{\boldsymbol{\mu}}_{P i}\right)+\left\langle x_{n i}{ }^{2}\right\rangle \tilde{W}_{i}^{T} \tilde{W}_{i}\right\}}
\end{gathered}
$$
ここで, $\tilde{\pi}_{i}, \tilde{\mu}_{P i}, \tilde{\mu}_{S i}, \tilde{W}_{i}, \quad \tilde{\sigma} P_{i}^{2}$ は更新されたパラメータを表す. 各パラメータが収束するまで, $\mathrm{E}$ ステップと $\mathrm{M}$ ステップを繰り返し 行うことにより, 最尤推定量 $\hat{\theta}=\left\{\hat{\theta}_{i} ; i=1, \ldots, M\right\}$ が得られる.ここ で $\hat{\theta}_{i}$ は次式とする.

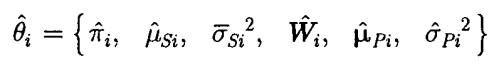

（15)式に(31)式を用いて推定された確率分布は次式のようになる.

$$
\begin{aligned}
p(x, \boldsymbol{y})=\sum_{i=1}^{M} & \hat{\pi}_{i} \mathcal{N}\left(y_{S} ; \hat{\mu}_{S i}, \bar{\sigma}_{S i}{ }^{2}\right) \\
& \times \mathcal{N}\left(\boldsymbol{y}_{P} ; \hat{\boldsymbol{W}}_{i} x+\hat{\boldsymbol{\mu}}_{P i}, \hat{\sigma}_{P i}{ }^{2} \boldsymbol{I}_{\boldsymbol{d}}\right) \mathcal{N}(x ; 0,1)
\end{aligned}
$$

(32)式から条件つき期待值 $E\left(y_{P} \mid y_{S}, x\right)$ が次式のように得られる.

(Appendix1)

$$
E\left(\boldsymbol{y}_{P} \mid y_{S}, x\right)=\frac{\sum_{i=1}^{M} \hat{\pi}_{i} \mathcal{N}\left(y_{S} ; \hat{\mu}_{S i}, \bar{\sigma}_{S i}{ }^{2}\right) \mathcal{N}(x ; 0,1)\left\{\hat{\boldsymbol{W}}_{i} x+\hat{\boldsymbol{\mu}}_{P i}\right\}}{\sum_{i=1}^{M} \hat{\pi}_{i} \mathcal{N}\left(y_{S} ; \hat{\mu}_{S i}, \bar{\sigma}_{S i}{ }^{2}\right) \mathcal{N}(x ; 0,1)}
$$

（33)式は確率的定式化に基づいた部材断面表現であり，部材断面系 列指標 $y_{S}$, および部材断面系列内指標 $x$ が与えられた下での部材断 面に関する量 $y_{P}$ を表現する関数と解釈できる.

また，部材幅も観測される性能量として $y_{P}$ に含めれば，隠れ変 数に対応する期待值を得るように定式化することも可能である.

\section{3. 最適設計問題}

部材断面を表現する関数である(33)式を用いて，次のような動的 応答を制約条件とした鋼構造建築骨組の最適設計問題を考える. 


\section{最適設計問題}

指定された設計用地震動に対して，指定された忘答評価法による 最大層間変形角制約条件

$$
\delta_{i \max }\left(x_{D}\right) \leq \overline{\delta_{i}}
$$

を満足し，かつ目的関数（部材総重量）

$$
f\left(x_{D}\right)=\rho \sum_{j} A_{j}\left(x_{D}\right) l_{j}
$$

を最小化するような設計変数分布 $x_{D}$ を求めよ。

ここで, $\delta_{i \max }\left(x_{D}\right)$ は第 $i$ 層に生じる最大層間変形角を表し, $A_{j}\left(x_{D}\right)$ および $l_{j}$ はそれぞれ，第 $j$ 部材の断面積および材長を表し， $\rho$ は鉄骨比重を表す，各部材において，部材断面系列指標 $y_{S}$ ，およ び部材断面系列内指標 $x$ を設計変数として選び，これらをまとめて 設計変数分布 $x_{D}=\left\{x_{D j}\right\}$ とする.

本手法による部材断面表現は, 設計変数に対して部材断面性能が 滑らかではあるが非単調な関数となるため, 最適化問題の構造が複 雑となり, 局所最適解に陥りやすくなることが予想される、しかし, 制約条件を满足する建設可能な性質のよい局所最適解であれば，目 的とする設計の論理化は十分達成されると考える.

\section{3. 数値解析例}

本手法を適用した数值解析例を以下に示す.

\section{1. 部材断面確率モデル}

全部材に $\mathrm{H}$ 形鋼を使用することを想定し,梁はハイパービーム ${ }^{8)}$, 柱は広幅系列 8) に含まれる断面を対象とする. ただし，本例では各 性能量に関して対数空間上で平均が 0 , 分散が 1 となるようにデー タを標準化して用いる.

梁部材に関しては，各層で部材せいをそろえることを前提として 部材せい $H$ を部材断面系列指標 $y_{S}$ として扱い, $y_{P}$ に対応する $x$ と あわせて設計変数とする，柱は部材せい $H$ を考慮せずに $y_{P}$ に対応

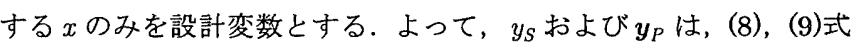
に定義した通りとする. 第 $j$ 部材に関する量に $j$ をつけて設計変数 を表せば，柱，梁ではそれぞれ次のように表せる。

$$
\text { 第 } j \text { 部材が梁の場合の設計変数 : } \boldsymbol{x}_{D j}=\left\{y_{S j}, x_{j}\right\}
$$$$
\text { 第 } j \text { 部材が柱の場合の設計変数 : } \boldsymbol{x}_{D j}=\left\{x_{j}\right\}
$$

同じ部材せいとなる断面の集合ごとに主成分分析を行って得られた パラメータを初期値として, EM ステップを 100 回繰り返し最尤推 定を行った. $\bar{\sigma}_{S i}{ }^{2}$ は仮想的な系列の分散であり，部材断面リスト全 体から求められる部材せい $H$ に関する標準偏差を $\sigma_{S 0}$ として, $\bar{\sigma}_{S i}=0.3 \sigma_{S 0}$ と設定した.

本例題において，(32)式から得られる確率分布 $p(x, \boldsymbol{y})$ の例として, ハイパービームに関する周辺密度関数 $\dot{p}(H, A), p\left(H, I_{x}\right)$ の等高線 をそれぞれ図 2，3 に部材断面リストとあわせて示す. (Appendix1)

(33)式加得られる期待值 $E\left(y_{P} \mid y_{S}, x\right)$ の例として, $E(A \mid H, x)$, $E\left(I_{x} \mid H, x\right), \quad E\left(Z_{x} \mid H, x\right), \quad E\left(A, I_{x} \mid H, x\right), \quad E\left(A, Z_{x} \mid H, x\right)$ を, それぞれ図 4 から図 8 に部材断面リストとあわせて示す。ただし， $400 \leq y_{S}(=H) \leq 900 ，-2 \leq x \leq 2$ としている. なお， $p(x)=\mathcal{N}(x ; 0,1)$ であるので, $-2 \leq x \leq 2$ の範囲では約 $95 \%$ の確 率で与えられた部材断面が含まれることになる，また，図中の部材 断面リストに含まれる各断面の隠れ変数 $x$ は部材断面性能に関する

量 $y$ が与えられた下での条件つき期待值 $E(x \mid y)$ として求めてい る. (Appendix4) 図 4 から図 8 より，与えられた部材断面リスト


良好な関数として得られていることが確認される.



図 $2 p(H, A)$

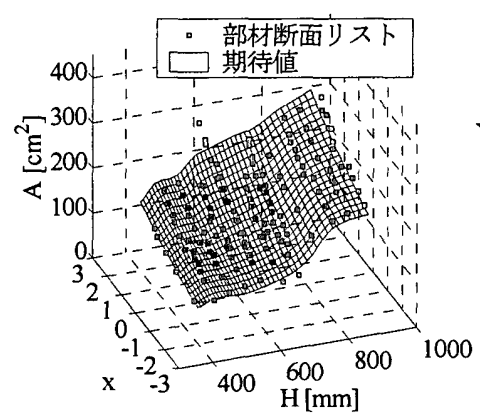

図 $4 E(A \mid H, x)$

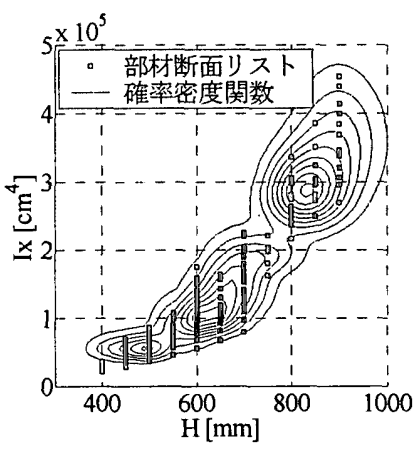

図 $3 p\left(H, I_{x}\right)$

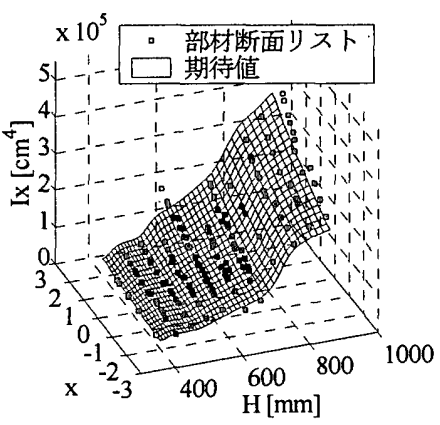

図 $5 E\left(I_{x} \mid H, x\right)$

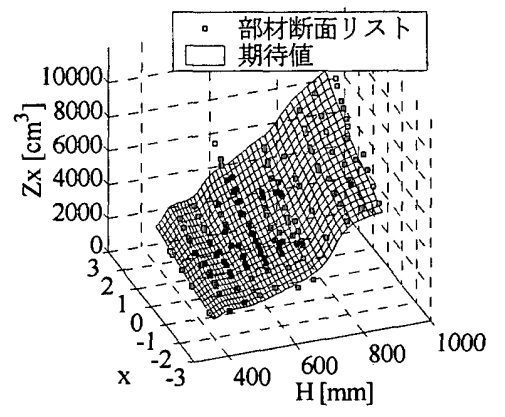

図 $6 E\left(Z_{x} \mid H, x\right)$

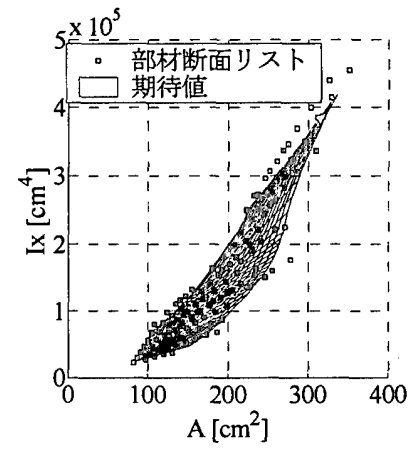

図 $7 E\left(A, I_{x} \mid H, x\right)$

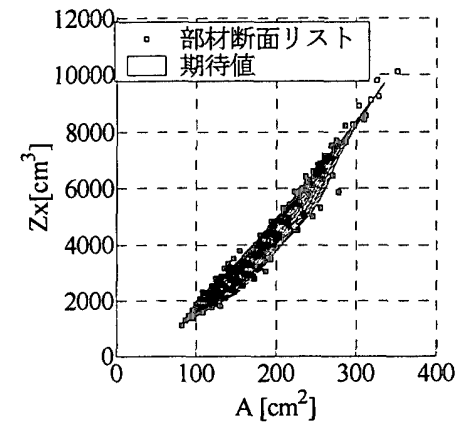

図 $8 E\left(A, Z_{x} \mid H, x\right)$ 
なお， $\bar{\sigma}_{S i}=0.3 \sigma_{S 0}$ 以外の值を設定することもできる. $\bar{\sigma}_{S i}$ の値 を小さくすれば，他の系列から受ける影響が少なくなり，よりデー 夕の特徵に適合した分布関数が得られる.ただしあまり小さな值に 設定すると分布関数が滑らかではなくなり，多峰性が強まり，局所 最適解に陥りやすくなることが想定される.このように考えれば, $\bar{\sigma}_{S i}$ は滑らかさに関するパラメータとも解䣋される．比較のために, $\bar{\sigma}_{S i}=0.15 \sigma_{S 0}$ と設定して得られた $E(A \mid H, x), E\left(I_{x} \mid H, x\right)$ を図 9, 10 にそれぞれ示す．より断面の特徴に適合しているが，滑らかでは ない分布が得られていることがわかる.

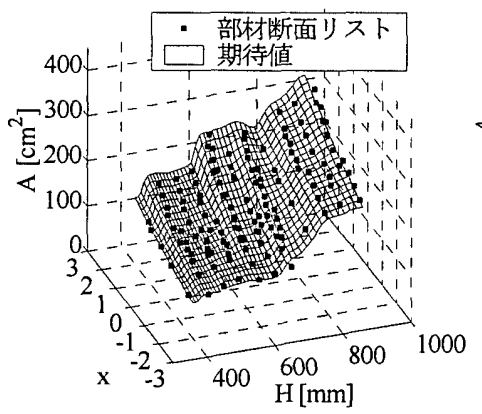

図 $9 E(A \mid H, x)$



図 $10 E\left(I_{x} \mid H, x\right)$

\section{2. 解析モデル}

図 11 に示す 10 層 3 スパンの平面弾性骨組モデルを対象とし, 柱 部材は 2 層ごとに, 梁部材は 1 層ごとに対称に位置する部材を等し いとし, さらに 2 層ごとに梁せいが等しくなるようにグルーピング を行う.よって設計変数を,柱部材において部材断面系列内指標 $x$ が 10 個, 梁部材において部材断面系列内指標 $x$ が 20 個, 部材断面系 列指標 $y_{S}(=H)$ が 5 個の計 35 個とする.



図 1110 層 3 スパン平面弾性骨組モデル

設計用地震動としてレベル 1 に相当するようにスケーリングした El Centro 1940 NS 記録地震波, Taft $1952 \mathrm{EW}$ 記録地震波, およ び Newmark and Hallによる Design Spectrum を簡略化したもの を採用する，応答評価法として，一次固有モードのみを考慮した応 答スペクトル法を採用し, 最大層間変形角を $1 / 200$ 以下とする．ま た，用いる态答スペクトルの減衰定数は $2 \%$ とする.

なお，本例題では解析に用いる断面性能は $A ， I_{x}$ のみに限られる が，その他の断面性能に関する情報も，例えば $Z_{x}$ に関して図 6,8 に示したように得られており, その他の断面性能が必要となるよう な解析を行うことも可能である.

\section{3. 最適解}

本例題では，逐次二次計画法により最適解を得た，柱，梁それぞ れについて，得られた最適解と部材断面リストの分布を，図 12 か ら図 16 に示す。図 12 から図 16 より，部材断面リストの分布に近 い最適解が得られていることが確認される. 図 14 より，断面積に 対して断面二次モーメントが大きな部材断面が解として多く得られ ている．また，異なる初期值とした場合でも，求められた最適解の 目的関数值はほぼ等しい值となったので, 得られた最適解は劣悪な 局所最適解ではないことが予想される.

得られた最適解が断面の離散化選択にも有用であることを確認 するために，最適解に対して，各断面の $H ， I_{x}$ がそれぞれ大きく なり，かつ $A$ の変動量が最小となる断面を選択する．ただし， $H$ は 隣の系列より大きくはしないとする。ここでは，このようにして得 られた離散解をラウンドアップ.解と呼ぶ. ラウンドアップ解と部材 断面リストの分布を図 $17,18 ， 19$ に示寸.

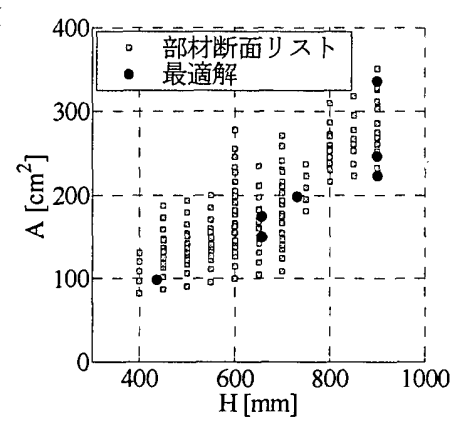

図 12 梁の最適解 $(H, A)$



図 14 梁の最適解 $\left(A, I_{x}\right)$

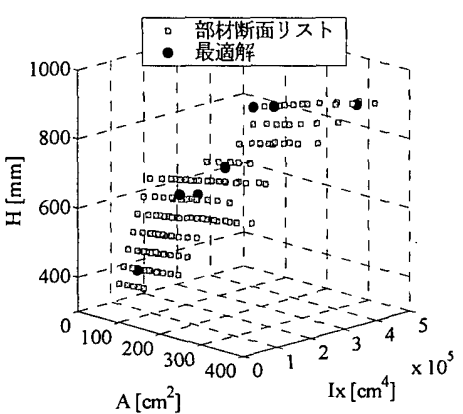

図 16 梁の最適解 $\left(A, I_{x}, H\right)$

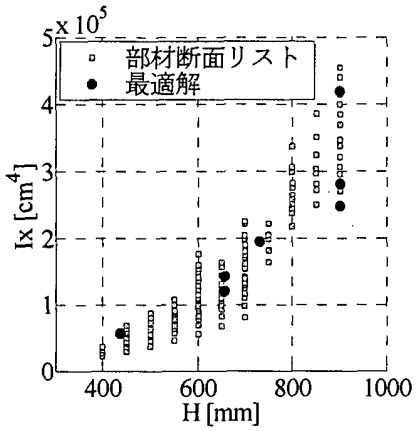

図 13 梁の最適解 $\left(H, I_{x}\right)$

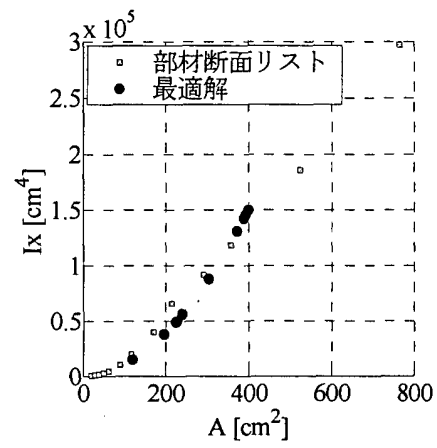

図 15 柱の最適解 $\left(A, I_{x}\right)$



図 17 梁のラウンドアップ解 $\left(A, I_{x}, H\right)$ 


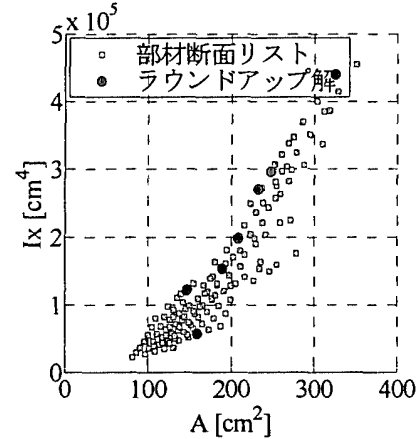

図 18 梁のラウンドアップ解 $\left(A, I_{x}\right)$



図 19 柱のラウンドアップ解 $\left(A, I_{x}\right)$
図 14，15，16 と図 17，18，19 を比較することにより，ラウンド アップ解と最適解では断面の分布が近いものとなっていることがわ かる.

最適解とラウンドアップ解における総体積と層間変形角（制約条 件）をぞれぞれ表 1 に示す．部材せいを含めた複雑なグルーピング を考慮した本例題において，このような単純な断面選択方法でも， $12 \%$ 程度の目的関数の增加で制約条件をほぼ満足する解が得られて いる. 本手法により得られる最適解を初期解として，より効率的な 離散化アルゴリズムを適用すれば，厳密に制約条件を満たしたより 良好な離散解が得られることが予想される。また，必ずしも離散化 アルゴリズムを適用しなくとも, 部材断面系列指標 $y_{S}$ と部材断面系 列内指摽 $x$ が各断面ごとに得られているので，これらを基に設計者 が部材断面を決定することも容易である.

表 1 最適解とラウンドアップ解の比較

\begin{tabular}{|c|c|c|c|}
\hline \multicolumn{2}{|c|}{} & 最適解 & ラウンドアップ解 \\
\hline \multicolumn{1}{|c|}{ 総体積 $\left[\mathrm{m}^{3}\right]$} & 10.10 & 11.34 \\
\hline \multirow{4}{*}{} & $1 \mathrm{~F}$ & 3.74 & 3.27 \\
\cline { 2 - 4 } & $2 \mathrm{~F}$ & 5.00 & 4.53 \\
\cline { 2 - 4 } & $3 \mathrm{~F}$ & 5.00 & 4.58 \\
\cline { 2 - 4 } & $4 \mathrm{~F}$ & 5.00 & 4.61 \\
\cline { 2 - 4 } $\begin{array}{c}\text { 変間 } \\
\times 10^{-3} \\
{[\mathrm{rad}]}\end{array}$ & $5 \mathrm{~F}$ & 5.00 & 4.68 \\
\cline { 2 - 4 } & $6 \mathrm{~F}$ & 4.90 & 4.70 \\
\cline { 2 - 4 } & $7 \mathrm{~F}$ & 5.00 & 4.82 \\
\cline { 2 - 4 } & $8 \mathrm{~F}$ & 4.70 & 4.61 \\
\cline { 2 - 4 } & $9 \mathrm{~F}$ & 5.00 & 5.09 \\
\cline { 2 - 4 } & $10 \mathrm{~F}$ & 3.65 & 3.73 \\
\hline
\end{tabular}

\section{4. 結論}

与えられた $\mathrm{H}$ 形鋼材の部材断面リストに関して, 確率的な定式化 に基づき部材断面を表現し，最適解を得る手法を提案した。

（1）与えられた $\mathrm{H}$ 形鋼材の部材断面リストの特徴を系列に着目し て，確率的に定式化することにより，物理的に独立と考えられる設 計変数空間よりも低次元な特徵空間で最適化問題を考え, 問題の自 由度を小さくできることを示した。例題より得られる最適解は部材 断面リストの特徴を精度よく表現していることを確認した。

（2）部材断面性能と部材断面形状の関係を考慮して変数表現をし た．本手法を用いれば，各層ごとに梁せいをそろえるといった部材
断面形状に関する条件も考慮可能である.このような条件を考慮し た場合には，断面積に対して断面二次モーメントが大きくないよう な部材断面が最適解となることがある.

（3）本手法を用いれば，それぞれの部材断面がどのような断面と すればよいかの指標が得られる．設計者はこれらを設計の判断材料 として用いることができる.

\section{謝辞}

山崎 雅弘博士 (京都大学講師) から貴重な助言を頂戴した。ここに記して 謝意を表す。本研究の一部は（社）日本鉄銅連盟 平成 15 年度建築鋼構造研 究奨励金制度による援助を受けて行われた。

\section{参考文献}

1）中村恒善：建築骨組の最適設計，丸善， 1980

2）辻聖晃, 竹脇出, 上谷宏二：せん断型モデルの応答制約設計解を用いた建 築骨組の最適設計法, 日本建築学会近畿支部研究報告集, pp.117-120, 1999 3）澤田樹一郎，周岩，松尾彰，中村雄治：部材せい設計変数を考應した銅構 造建築骨組の最小重量設計に関する研究，日本建築学会構造系論文集，No544， pp.133·199, 2001.6

4) Tipping,M.E., Bishop,C.M. : Mixtures of Probabilistic Principal Component Analyzers, Neural Computation, Vol.11, pp.443-482, 1999

5）変分法的ベイズ推定による混合主成分分析：大羽成征,佐藤雅昭,石井信, 電子情報通信学会論文誌,Vol.J85·D-II, No.6, pp.1055·1064, 2002 6) Ghahramani, Z., Hinton, G.E. : The EM algorithm for mixtures of factor analyzers, Technical Report CRG-TR·96-1 (http://www.gatsby.ucl.ac.uk/ zoubin/papers/tr-96-1.ps.gz], Dept. of Comp. Sci., Univ. of Toronto, 1996 7) Moerland, P. : A comparison of mixture models for density estimation, Proceedings of the International Conference on Artificial Neural Networks (ICANN'99), pp.15-30, 1999

8）新日本製鐵株式会社：建設用資材ハンドブック，2000

Appendix 1

本論文で用いる表記を以下にまとめる. 確率変数 $(X, Y)$ の同時確率密度 関数を $p(x, y)$ とする. $X, Y$ のそれぞれの確率密度関数 $p(x), p(y)$ は, 興味のない変数について累積（積分）をとることで得られる.

$$
p(x)=\int p(x, y) d y, \quad p(y)=\int p(x, y) d x
$$

このようにして得られる $p(x), p(y)$ を周辺密度関数とよぶ. $X=x$ であ ることが与えられた下での $Y$ の確率密度関数を $Y$ の条件つき確率密度関数 とよび, $p(y \mid x)$ と表す. 条件つき確率密度関数 $p(y \mid x)$ は, ベイズの定 理より次式のように求めることができる.

$$
p(y \mid x)=\frac{p(x, y)}{p(x)}=\frac{p(x, y)}{\int p(x, y) d y}
$$

条件つき確率密度関数 $p(y \mid x)$ に関して，X=xであることが与えられた 下での $Y$ の期待值 (平均值) を $E(Y \mid x)$ と表す. $E(Y \mid x)$ は次式の上う に定義される。

$$
E(Y \mid x)=\int y p(y \mid x) d y=\frac{\int y p(x, y) d y}{\int p(x, y) d y}
$$




\section{Appendix 2}

確率密度関数 $p(y)$ がパラメータ $\theta$ によって定まる場合には， $p(y ; \theta)$ と 表す、確率モデルでは，観測変数を確率変数の実現值とみなし，データ $Y=\left\{y_{n} ; n=1, \ldots, N\right\}$ を観測した時，

$$
L(\theta)=p(Y ; \theta)=\prod_{n=1}^{N} p\left(\boldsymbol{y}_{n} ; \theta\right)
$$

を $\theta$ の尤度関数と呼ぶ. 確率の大きな事象ほど起こりやすいのだから， $L(\theta)$ が最大となるようにパラメータ $\theta$ の值を決めればよい， $L(\theta)$ の代わりに, 対数尤度関数

$$
\mathcal{L}(\theta)=\ln L(\theta)=\sum_{n=1}^{N} \ln p\left(\boldsymbol{y}_{n} ; \theta\right)
$$

を最大にしてもよいこのようにパラメータ $\theta$ を決定する方法を最尤法 (maximum likelihood method) と呼び， $L(\theta)$ または $\mathcal{L}(\theta)$ を最大とする ような $\theta$ を最尤推定量と呼ぶ.

\section{Appendix 3}

（14)式より, 観測変数 $y$ に関する周辺密度関数は次式のように得られる.

$$
\begin{aligned}
p\left(\boldsymbol{y} \mid m_{i}\right) & =\int p\left(x, \boldsymbol{y} \mid m_{i}\right) d x \\
& =\mathcal{N}\left(y_{S} ; \mu_{S i}, \sigma_{S i}{ }^{2}\right) \mathcal{N}\left(\boldsymbol{y}_{P} ; \boldsymbol{\mu}_{P i}, \boldsymbol{C}_{y i}\right)
\end{aligned}
$$

ここで， $C_{y i}$ は(22)式で定義される，(14)，(A7)式より，観測変数 $\boldsymbol{y}$ および 部材断面系列 $m_{i}$ が与えられた下での隐れ変数 $x$ の条件つき確率密度関数は ベイズの定理より次式となる.

$$
\begin{aligned}
p\left(x \mid \boldsymbol{y}, m_{i}\right) & =\frac{p\left(x, \boldsymbol{y} \mid m_{i}\right)}{p\left(\boldsymbol{y} \mid m_{i}\right)} \\
& =\mathcal{N}\left(x ; C_{x i}{ }^{-1} \boldsymbol{W}_{i}{ }^{T}\left(\boldsymbol{y}_{P}-\boldsymbol{\mu}_{P i}\right), \sigma_{P i}{ }^{2} C_{x i}{ }^{-1}\right)
\end{aligned}
$$

ここで， $C_{x i}$ は(21)式で定義される， $y$ を観測した下での $m_{i}$ の事後分布 $p\left(m_{i} \mid \boldsymbol{y}\right)$ はべイズの定理より，次式となる.

$$
p\left(m_{i} \mid \boldsymbol{y}\right)=\frac{p\left(\boldsymbol{y}, m_{i}\right)}{p\left(\boldsymbol{y}_{n}\right)}=\frac{\pi_{i} p\left(\boldsymbol{y} \mid m_{i}\right)}{\sum_{j=1}^{m} \pi_{j} p\left(\boldsymbol{y} \mid m_{j}\right)}
$$

なお，(25)式では， $R_{n i}=p\left(m_{i} \mid y_{n}\right)$ として表している.

観測変数のサンプル $\left\{\boldsymbol{y}_{n} ; n=1, \cdots, N\right\}$ が与えられた下での対数尤度関数 $\mathcal{L}_{C}(\theta)$ の条件つき期待值 $Q(\theta)$ は，現在のパラメータ推定値を $\theta^{(t)}$ として， 次式のように表される。

$$
\begin{aligned}
Q(\theta)=\sum_{n=1}^{N} \sum_{i=1}^{M} p\left(m_{i} \mid \boldsymbol{y}_{n} ; \theta^{(t)}\right) & \\
& \times \int p\left(x \mid \boldsymbol{y}_{n}, m_{i} ; \theta^{(t)}\right) \ln \left\{\pi_{i} p\left(x_{n}, \boldsymbol{y}_{n} \mid m_{i} ; \theta\right)\right\} d x
\end{aligned}
$$

(A10)

(A10)式に(A7)，(A8)，(A9)式を用いることにより，(20)式の表現が得られる. これは, 現在のパラメータ推定值 $\theta^{(t)}$ に基づいて算出される隐れ変数の事後 分布(A8)，(A9)式によって，不完全情報を暫定的に補っていると解釈できる.

\section{Appendix 4}

観測変数 $y$ が与えられた下での鿵れ変数 $x$ の条件つき期待值は次式とな

$$
\begin{aligned}
E(x \mid \boldsymbol{y}) & =\int x p(x \mid y) d x \\
& =\int x \frac{p(x, \boldsymbol{y})}{p(\boldsymbol{y})} d x \\
& =\int x \frac{\sum_{i=1}^{M} \pi_{i} p\left(x \mid y, m_{i}\right) p\left(\boldsymbol{y} \mid m_{i}\right)}{\sum_{i=1}^{M} p\left(\boldsymbol{y} \mid m_{i}\right)} d x
\end{aligned}
$$

ここで，(A7)(A8)式を用いれば次式が得られる.

$E(x \mid y)=\frac{\sum_{i=1}^{M} \pi_{i} C_{x i}{ }^{-1} W_{i}{ }^{T}\left(\boldsymbol{y}_{P}-\boldsymbol{\mu}_{P i}\right) \mathcal{N}\left(y_{S} ; \mu_{S i}, \sigma_{S i}{ }^{2}\right) \mathcal{N}\left(\boldsymbol{y}_{P} ; \boldsymbol{\mu}_{P i}, C_{y i}\right)}{\sum_{i=1}^{M} \pi_{i} \mathcal{N}\left(y_{S} ; \mu_{S i}, \sigma_{S i}{ }^{2}\right) \mathcal{N}\left(\boldsymbol{y}_{P} ; \boldsymbol{\mu}_{P i}, C_{y i}\right)}$

(A12)

(2004年 3 月 10 日原稿受理，2004年 6 月 7 日採用決定) 